\title{
Several key reasons why a paper is likely to be rejected at the Asia Pacific Journal of Management
}

\author{
David Ahlstrom
}

Published online: 1 August 2012

(C) Springer Science+Business Media, LLC 2012

At the Asia Pacific Journal of Management (APJM) part of our mission is to give help and feedback to prospective authors whenever feasible. APJM regularly publishes the work of some authors new to this field and we take great effort in giving authors guidance during the review process and through the editorials, perspectives, and commentary articles we publish (e.g., Ahlstrom, 2010a, b, c, 2011a, b, c, 2012a; Liden, 2012). Prospective authors who want to learn about the research and publishing process should read these and other helpful materials from the Academy of Management Journal and other sources cited in those editorial articles (e.g., Colquitt \& George, 2011; Colquitt \& Ireland, 2009; Schminke, 2004). ${ }^{1}$ As noted in past editorials (Ahlstrom, 2012a), APJM publishes articles ranging from empirical studies, cases, conceptual and theory building papers, to reviews, perspectives, and commentaries (e.g., Ahlstrom, Lamond, \& Ding, 2009; Bhagat, McDevitt, \& McDevitt, 2010; Fang, 2010; Ismail \& Ford, 2010; Lahiri, 2011; Li, 2012; Liden, 2012; Meyer, 2006; Puffer, \& McCarthy, 2007; van Essen, van Oosterhout, \& Carney, 2012; Yang, Tipton, \& Li, 2011; Zhou \& Peng, 2010). ${ }^{2}$ Authors should take care to read the papers that are most relevant to their work so as to better understand APJM's aims and scope and what the journal typically publishes.

As with many of the better management journals, APJM has a fairly high rejection rate: currently near 90 percent. Some of these rejections probably could have been

\footnotetext{
${ }^{1}$ The editorial article "Some helpful sources for prospective authors in Asia Pacific Journal of Management" (Ahlstrom, 2011c) cites and discusses a number of sources on a range of publishing topics, which prospective authors may find helpful.

${ }^{2}$ Cases here do not refer to classroom cases, but cases that help to build or improve theory (see Flyvbjerg, 2006).
}

The Asia Pacific Journal of Management would like to thank Rachel "Rae" Pinkham for her continued editorial and fine research assistance. And our editorial team would like to offer special thanks and congratulations to Saraswathi "Sara" Sabapathy (née Ramaswamy) of Springer-India on her recent wedding. During that busy time, Sara worked extra hard in helping us with the challenging task of getting an oversized Special Issue of the journal (issue 2 of 2012 Leadership in Asia) ready for publication.

D. Ahlstrom $(\bowtie)$

Department of Management, The Chinese University of Hong Kong, Shatin, NT, Hong Kong e-mail: ahlstrom@baf.msmail.cuhk.edu.hk 
avoided if authors had been more careful to read the articles mentioned here and utilize their advice. Authors should also familiarize themselves with some of the most common reasons why papers are rejected, particularly in the field of management and organizations (e.g., Daft, 1995) as the peer review process is fundamental to scientific research and publishing (Yuksel, 2003). A number of articles have been written on this from various sources, including $A P J M$, and although they may come from different journals, the guidance is consistent and complementary (e.g., Ahlstrom, 2010b, c, 2011b; Kilduff, 2007; Schminke, 2004). This editorial article summarizes, based on $A P J M$ editor and reviewer letters in recent years (and drawing on some other sources), several of the most common reasons why papers have been rejected at APJM. This is not intended to be a comprehensive list of rejection reasons, rather this paper simply summarizes some of the most common reasons and gives some suggested remedies.

\section{Weak research question and topic outside of $A P J M$ 's aims and scope}

This problem with manuscripts submitted to $A P J M$ has been discussed in several of my previous editorials (Ahlstrom, 2010b, c, 2011a). But what bears repeating is authors should avoid stating only that they are going to "investigate" or "examine" some (often broad) issue. Good research papers in the social sciences almost always ask a very specific question or research a fairly narrow thesis topic. Simply stating that you are going to examine goal setting in India (or some other place), for example, is not a suitably narrow or justifiable topic for $A P J M$. Imagine a scientist requesting a grant stating that he or she was going to "examine the Moon." Even someone unschooled in physics and cosmology would immediately wonder why that scientist would seek to study such a well-researched phenomenon. That is, what does that scientist really want to learn about the Moon that is not known today and why would it be important? Similarly, goal setting probably does not need to be "examined" or "explored" at this stage of the research's development on that key topic. ${ }^{3}$ Very specific questions (and hypotheses) with some theory significance need to be answered. Many important questions about goal setting certainly remain, some of which could well be answered by studies from around Asia. Yet authors need to be very familiar with the extant research and the key questions that remain unanswered. The excellent papers by Ed Locke and colleagues are a fine start in understanding goal setting and the needed research on that topic (Latham \& Locke, 2009; Locke \& Latham, 2009). Authors should seek comparable perspectives papers or other thorough reviews of the literature to better understand the key unanswered questions in their field of research (e.g. Ahlstrom, Chen, \& Yeh, 2010).

Another general research approach that would probably not be appropriate for $A P J M$ is one that discusses a topic strictly about a particular country, region, or industrial sector with little contribution to theory in management and organizations. Quite often, this problem arises when a paper is submitted on a subject or theory area that has been covered effectively before or simply replicates the methods of a past paper, often with a simple structure of causal variables that have already been confirmed by previous studies. Such a paper often argues that its contribution lies

\footnotetext{
${ }^{3}$ Perhaps an exploratory study on goal setting could be conducted, but the authors would have to carefully justify its need by the past research on the topic, of which there is now a great deal.
} 
in replicating the study in a new research site or location. That alone, however, is not a convincing argument. Just because a phenomenon has not been studied in a particular industry or country is not enough of a reason on its own to do a study. A paper will need to explain why such a study can add to our knowledge on management and organizations, particularly from a theory standpoint. It is important for the paper to show what its contribution to theory is, and why it is interesting and helpful to study this topic in a novel research site (Ahlstrom, 2010a).

Research sites around the Asia Pacific region are certainly what APJM seeks in its manuscript submissions. Yet when the author focuses only on reporting the information that the data set provides and little else, problems of (a lack of) contributions often arise. For example, if a paper sought to describe the Chinese beverage industry in some detail, that could constitute a potential empirical contribution to the management literature. But just providing that description, and simply confirming that a certain established theory seemed to work in the Chinese beverage industry probably would not provide a significant enough contribution to management and organizational theory. Similarly, evaluating a new program by a Malaysian State in promoting start-up firms in their electronics sector would also not provide much contribution to management theory. APJM is not a forum for public policy evaluations and purely empirical assessments of new programs. Similarly, a paper that focused mostly on evaluating an application of a method such as DEA analysis or Fourier Series Analysis would not be appropriate for APJM, unless the authors were able to address some issue that management researchers would be interested in, such as how those interesting methods could help to answer some key mainstream management questions. APJM seeks research that builds, tests, improves, or otherwise contributes to theory on (or relevant to) the Asia Pacific region (e.g., Ahlstrom, 2011a; Colquitt \& Ireland, 2009; Corley \& Gioia, 2011; Whetten, 1989). A study could and should have empirical and important practice or policy contributions (Ahlstrom, 2012a, b), but it is incumbent on the authors to show this through a careful survey of past literature and how the paper adds to or improves theory and research (Christensen \& Carlile, 2009).

\section{Failing to situate the paper in past literature}

As noted above, in selecting a topic that provides a contribution to theory, the paper also should be situated or positioned in terms of that literature (Ahlstrom, 2011b). This positioning of the paper is often termed "filling a gap" in the literature by authors. I find that term to be a little misleading, as researchers should test and improve theories so they can be used prescriptively by managers, supervisors, consultants, and other researchers. ${ }^{4}$ Perhaps "point of departure" from past theory is a more suitable metaphor than "gap filling." Regardless of the terms used, at APJM, we have found that authors consistently make two major mistakes in the area of literature review and situating or motivating the need for their papers. First, authors often fail to acknowledge that much of any research has come before. APJM often gets papers that

\footnotetext{
${ }^{4}$ For example, research on institutions, venture capital, private equity, compensation, and several other topics have increasingly shown up in the law literature, particularly papers from the international business and international management areas.
} 
state (incorrectly) that little or no research has been done on a particular topic. For example, one manuscript we received argued that only a little research had been done on the topic of social influence, and that there were a number of incommensurable models in the field that needed reconciling. While the variety of models may be true and hence potentially a good start to the paper, the authors then only cited a few of publications on this very large stream of research in social psychology and leadership, and most of the papers cited were over 25 years old. It was evident from the very limited literature review that the authors did not know the past research on the topic and therefore were unable to show how their paper contributed to that extensive literature.

Second, sometimes a paper will again state that not much research has been done, but only with respect to one particular industry, organizational sector, or region. We receive many manuscripts that will research a specialty topic such as the motivation of police in a northern Indian state, for example. The author will then position and justify that paper by saying, "no research has been done on the motivation of police in this Indian state, and therefore this fills a gap in the literature." As noted earlier also, APJM receives many papers like this, which justify the need for the paper on a novel organizational sector or research site, or both. It is important that a manuscript situates itself properly in past research, and thus has a research topic that can address theory, and make a meaningful theory contribution (as well as any helpful empirical and practice contributions), especially if the topic is a practical one, such as a study of a particular occupation. Authors need to say why this particular topic and research site fits with and extends past literature, and how it provides some theory contribution and not just an empirical one by virtue of being a new research site. This should be done briefly in the introduction, and then the contributions should be more formally stated in the discussion section of the paper (Ahlstrom, 2011b; Meyer, Estrin, Bhaumik, \& Peng, 2009). Research in a novel sector in a largely unstudied region may constitute an empirical contribution, but the author must situate the paper in past research on the relevant theory lens and then show how the paper provides a theory contribution, as well as other contributions. 5

Additional guidance on theory contributions is available in a number of sources (e.g., Colquitt \& Ireland, 2009; Corley \& Gioia, 2011; Van de Ven, 2007; Whetten, 1989) as well as other types of contributions (Ahlstrom, 2011b, 2012b). For contributions to practice, some helpful works include Bartunek and Rynes (2010), Christensen and Raynor (2003), and Peng and Dess (2010). Some good examples of empirical contributions (as well as others such as methods) can be found in Meyer et al. (2009), Peng, Li, Xie, and Su (2010), and Rynes et al. (2005) as well as many other papers. Readers interested in learning more on the important topic of contributions to theory, empirical or case evidence, practice, methods, and the literature review should watch for these topics in future editorials or commentaries of APJM, and look up some of the helpful sources discussed here.

\footnotetext{
${ }^{5}$ Phenomenological papers that are exploratory and help to identify a novel phenomenon or new theory are certainly welcome (see Hambrick, 2007). But as noted, authors should be careful that they understand and have reviewed the literature such that a phenomenological or exploratory paper is warranted by the lack of theory on that topic (Christensen \& Carlile, 2009).
} 


\section{References}

Ahlstrom, D. 2010a. Publishing in the Asia Pacific Journal of Management. Asia Pacific Journal of Management, 27(1): 1-8.

Ahlstrom, D. 2010b. Clearing the first hurdle at the Asia Pacific Journal of Management. Asia Pacific Journal of Management, 27(2): 171-177.

Ahlstrom, D. 2010c. Avoiding common missteps: Writing papers suitable for the Asia Pacific Journal of Management. Asia Pacific Journal of Management, 27(4): 583-586.

Ahlstrom, D. 2011a. On the aims and scope of the Asia Pacific Journal of Management: What does APJM really seek to publish?. Asia Pacific Journal of Management, 28(2): 215-219.

Ahlstrom, D. 2011b. A checklist for prospective authors of Asia Pacific Journal of Management. Asia Pacific Journal of Management, 28(3): 449-452.

Ahlstrom, D. 2011c. Some helpful sources for prospective authors in Asia Pacific Journal of Management. Asia Pacific Journal of Management, 28(4): 661-665.

Ahlstrom, D. 2012a. On the types of papers the Asia Pacific Journal of Management generally publishes. Asia Pacific Journal of Management, 29(1): 1-7.

Ahlstrom, D. 2012b. Contributing to the Asia Pacific Journal of Management. Asia Pacific Journal of Management, 29(2): 191-194.

Ahlstrom, D., Chen, S.-j., \& Yeh, K. S. 2010. Managing in ethnic Chinese communities: Culture, institutions, and context. Asia Pacific Journal of Management, 27(3): 341-354.

Ahlstrom, D., Lamond, D., \& Ding, Z. 2009. Reexamining some management lessons from military history. Asia Pacific Journal of Management, 26(4): 617-642.

Bartunek, J. M., \& Rynes, S. L. 2010. The construction and contributions of "implications for practice": What's in them and what might they offer?. Academy of Management Learning and Education, 9(1): $100-117$.

Bhagat, R. S., McDevitt, A. S., \& McDevitt, I. 2010. On improving the robustness of Asian management theories: Theoretical anchors in the era of globalization. Asia Pacific Journal of Management, 27(2): $179-192$.

Christensen, C. M., \& Carlile, P. E. 2009. Course research: Using the case method to build and teach management theory. Academy of Management Learning and Education, 8(2): 240-251.

Christensen, C. M., \& Raynor, M. E. 2003. Why hard-nosed executives should care about management theory. Harvard Business Review, 81(9): 66-74.

Colquitt, J. A., \& George, G. 2011. From the editors. Publishing in AMJ_Part 1: Topic choice. Academy of Management Journal, 54(3): 432-435.

Colquitt, J. A., \& Ireland, R. D. 2009. From the editors: Taking the mystery out of AMJ's reviewer evaluation form. Academy of Management Journal, 52(2): 224-228.

Corley, K. G., \& Gioia, D. A. 2011. Building theory about theory building: What constitutes a theoretical contribution?. Academy of Management Review, 36(1): 12-32.

Daft, R. 1995. Why I recommended that your manuscript be rejected and what you can do about it. In L. L. Cummings \& P. J. Frost (Eds.). Publishing in the organizational sciences, 2nd ed.: 164-182. Homewood, IL: Richard D. Irwin.

Fang, T. 2010. Asian management research needs more self-confidence: Reflection on Hofstede (2007) and beyond. Asia Pacific Journal of Management, 27(1): 155-170.

Flyvbjerg, B. 2006. Five misunderstandings about case-study research. Qualitative Inquiry, 12(2): 219-245.

Hambrick, D. 2007. The field of management's devotion to theory: Too much of a good thing?. Academy of Management Journal, 50: 1346-1352.

Ismail, K. M., \& Ford, D. L., Jr. 2010. Organizational leadership in Central Asia and the Caucasus: Research considerations and directions. Asia Pacific Journal of Management, 27(2): $321-340$.

Kilduff, M. 2007. Editor's comments: The top ten reasons why your paper might not be sent out for review. Academy of Management Review, 32: 700-702.

Lahiri, S. 2011. India-focused publications in leading international business journals. Asia Pacific Journal of Management, 28(2): 427-447.

Latham, G. P., \& Locke, E. A. 2009. Science and ethics: What should count as evidence against the use of goal setting?. Academy of Management Perspectives, 23(3): 88-91.

Li, P. P. 2012. Toward an integrative framework of indigenous research: The geocentric implications of Yin-Yang balance. Asia Pacific Journal of Management. doi:10.1007/s10490-011-9250-z. 
Liden, R. C. 2012. Leadership research in Asia: A brief assessment and suggestions for the future. Asia Pacific Journal of Management, 29(2): 205-212.

Locke, E. A., \& Latham, G. P. 2009. Has goal setting gone wild, or have its attackers abandoned good scholarship?. Academy of Management Perspectives, 23(1): 17-23.

Meyer, K. E. 2006. Asian management research needs more self-confidence. Asia Pacific Journal of Management, 23(2): 119-137.

Meyer, K. E., Estrin, S., Bhaumik, S., \& Peng, M. W. 2009. Institutions, resources, and entry strategies in emerging economies. Strategic Management Journal, 30(1): 61-80.

Peng, M. W., \& Dess, G. G. 2010. In the spirit of scholarship. Academy of Management Learning and Education, 9(2): 282-298.

Peng, M. W., Li, Y., Xie, E., \& Su, Z. 2010. CEO duality, organizational slack, and firm performance in China. Asia Pacific Journal of Management, 27(4): 611-624.

Puffer, S. M., \& McCarthy, D. J. 2007. Does Asian management research need more self-confidence? Reflections from Russia. Asia Pacific Journal of Management, 24(4): 509-517.

Rynes, S. L., Hillman, A., Ireland, R. D., Kirkman, B., Miller, C. C., Rajagopalan, N., \& Shapiro, D. 2005. From the editors: Everything you've always wanted to know about AMJ (but may have been afraid to ask). Academy of Management Journal, 48(5): 732-737.

Schminke, M. 2004. Raising the bamboo curtain. Academy of Management Journal, 47(3): 310-314.

Van de Ven, A. H. 2007. Engaged scholarship: A guide for organizational and social research. Oxford: Oxford University Press.

van Essen, M., van Oosterhout, J. H., \& Carney, M. 2012. Corporate boards and the performance of Asian firms: A meta-analysis. Asia Pacific Journal of Management. doi:10.1007/s10490-011-9269-1.

Whetten, D. A. 1989. What constitutes a theoretical contribution?. Academy of Management Review, 14(4): 490-495.

Yang, J. Y., Tipton, F. B., \& Li, J. T. 2011. A review of foreign business management in China. Asia Pacific Journal of Management, 28(3): 627-659.

Yuksel, A. 2003. Writing publishable papers. Tourism Management, 24(4): 437-446.

Zhou, J. Q., \& Peng, M. W. 2010. Relational exchanges versus arm's-length transactions during institutional transitions. Asia Pacific Journal of Management, 27(3): 355-370.

David Ahlstrom ( $\mathrm{PhD}$, New York University) is a professor at The Chinese University of Hong Kong. His research interests include managing in Asia, innovation and entrepreneurship, and management and organizational history. Professor Ahlstrom has published over 75 peer-reviewed articles in journals such as the Strategic Management Journal, Academy of Management Review, Journal of International Business Studies, Academy of Management Perspectives, and Organization Science. His work has also appeared on multiple occasions in The Wall Street Journal. Professor Ahlstrom co-authored the textbook International Management: Strategy and Culture in the Emerging World and guest edited two Special Issues of Entrepreneurship: Theory \& Practice. He has also guest edited two Special Issues of APJM: Turnaround in Asia in 2004 and Managing in Ethnic Chinese Communities in 2010, and was APJM Senior Editor during 2007-2009, and Editor-in-Chief from 2010-2012. Professor Ahlstrom also spent several years in start-up firms in before entering academia. 